\title{
Social Presence, Synchronous Tool Usage and Learning Performance in the e-Learning Classroom: What Is the Bottom Line?
}

\section{Yolanda Mathews $^{1} *$ \& Lelanie Basco ${ }^{1}$}

\section{* Correspondence: \\ lelaniembasco@yahoo.com \\ 1. International College, The University \\ of Suwon, South Korea}

Received: 8 September 2020

Revision: 22 October 2020

Accepted: 21 November 2020

Published online: 20 December 2020

\begin{abstract}
This study aimed to determine the university students' level of social presence, preferred synchronous learning tool, and learning performance and their differences according to sex, age, year, major, Blackboard experience, and perceived computer literacy. The relationship between students' social presence, preferred synchronous tool, and learning performance was also determined. The respondents were 29 students enrolled in the ESL online elective class, Global Business Communication, at a university in South Korea. There were two sets of online surveys used in this study. The statistical tools used in this study were the mean, Wilcoxon Signed Rank Test, Mann-Whitney Test, and Kruskal-Wallis Test. The results showed that the students maintained a Moderately High level of social presence throughout the duration of the course, chose KakaoTalk as their preferred synchronous learning tool, and concluded the course with an overall average grade, or learning performance level of "B." There was a significant difference regarding the students' learning performance when they were classified according to Blackboard experience; and no significant relationship existed between the students' social presence, preferred synchronous tool, and learning performance.
\end{abstract}

Keywords: blackboard, learning performance, e-Learning, social presence, synchronous online tools 


\section{Introduction}

Educational innovations are being aligned with the fast changing local and global demands of modern society. Traditional classroom setting, where the teachers and students meet face to face every class schedule is not the only venue for teaching and learning. Lessons can be delivered to students and learning can happen in many ways and in any form. Teaching and learning can be a face-to-face activity or simply an online activity in real time or in any time and place. In other words, learning can be synchronous or asynchronous. Synchronous learning happens live, in real time while asynchronous learning happens when students and instructors do not interact in real time and students can take the lessons at their own pace.

The adaptation of e-Learning classes gives the schools and universities the prerogative to use the learning tools to deliver the lessons to the students. Thus, different online learning platforms, social media, and specific social networks are most helpful in this educational innovations. Moreover, professors have to be updated with and knowledgeable to what could be more effective tool for their e-Learning classes. Likewise, it should also be of great consideration that the end goal of this innovations is to improve the learning performance of the students. That is to say, if the use of eLearning classroom is really effective in the students' learning performance.

Moreover, it is also noteworthy to know if the students are really willing to learn in an e-Learning classroom. It is as well interesting to find out what specific social network the students consider as most helpful in their learning process. South Korea is known for its fast internet services all throughout the country. Technology is always a part of every person's life from younger to older generations. In schools and universities, students are not without their phones wherever they are and whatever they do. This advancement in technology and availability of facilities are of great value to educational innovations such as e-Learning classrooms.

To give the educators a more realistic picture of the e-Learning classroom, it is better to see it in a specific situation. This study investigated the university students' level of social presence, preferred synchronous learning tools, and learning performance (final grades) in an elective e-Learning classroom.

\subsection{Research Questions}

Specific questions for this study are the following:

1. What are the students' levels of social presence before and after the conduct of the e-Learning course when they are classified according to age, sex, year, major, computer literacy level, and Blackboard experience and when taken as a whole?

2. What is the students' preferred synchronous learning tool when they are classified according to age, sex, year, major, computer literacy level, and Blackboard experience, respectively, and when taken as a whole?

3. What are the students' levels of learning performance when they are classified according to age, sex, year, major, computer literacy level, and Blackboard experience?

4. Is there a significant difference on the students' level of social presence in the e-Learning course?

5. Is there a significant difference on the students' level of learning performance in the e-Learning course?

6. Is there a significant relationship between the students' levels of social presence, preferred synchronous tool, and learning performance?

\subsection{Statement of the Problem}

The International College of The University of Suwon has engaged in the number and variety of online course offerings in the past two years. These include elective classes, such as Global Business Communication and English through TV Dramas, which are taught in either English or Chinese and open to all students. Considering the recent surge in research showing the positive effects of synchronous interaction on student engagement and learning outcomes in the online classroom (Duncan, Kenworthy, \& McNamara, 2012; Francescucci \& Rohan, 2018; Rabinowitch \& Knafo-Noam, 2015; Wang, 2008) as well as the learners' acceptance of e-learning services (Lee, Yoon, \& Lee, 2009) coupled with the absence or lack of related research utilizing English as a Second Language (ESL) students, an idea came up to conduct a study in an attempt to understand the lack of student participation and engagement in synchronous activities in the ESL department's online courses. Some professors began utilizing 
synchronous activities in their online classes in order to emulate the traditional, face-to-face classroom environment and enhance course presence and sense of community.

Regrettably, teachers were met with resistance by the students. Such resistance included a lack of or complete absence of participation in synchronous activities (Nagel, Blignaut, \& Cronje, 2009; Smith, Sorensen, Gump, Heindel, Caris, \& Martinez, 2011) and/or negative student feedback on course satisfaction surveys. Moreover, in The University of Suwon, some professors even reported receiving reduced, end-of-semester teacher evaluation scores because of, what they believed, was the addition of required synchronous participation in their courses. Consequently, some studies were carried out to implement various synchronous tools and activities in an effort to positively engage students in the use of synchronous communication activity (Bower, Dalgarno, Kennedy, Lee, \& Kenney, 2015; Ellis, Pardo, \& Han, 2016), increase social presence in the course and, ultimately, see improved scores as a result of this engagement.

The result of this study is significant for the educators who are doing online classes, specifically synchronous eLearning courses. Knowing the students' level of social presence will help the educators how to make their online courses more attractive and interesting to the students so they always attend the class and interact more with other students. In addition, lessons and activities can be done through the students' preferred synchronous learning tool. These would make the online teaching and learning more interesting, valuable, and productive for both the teachers and students.

\subsection{Conceptual Framework}

The conceptual framework of this study is shown in the following figure.

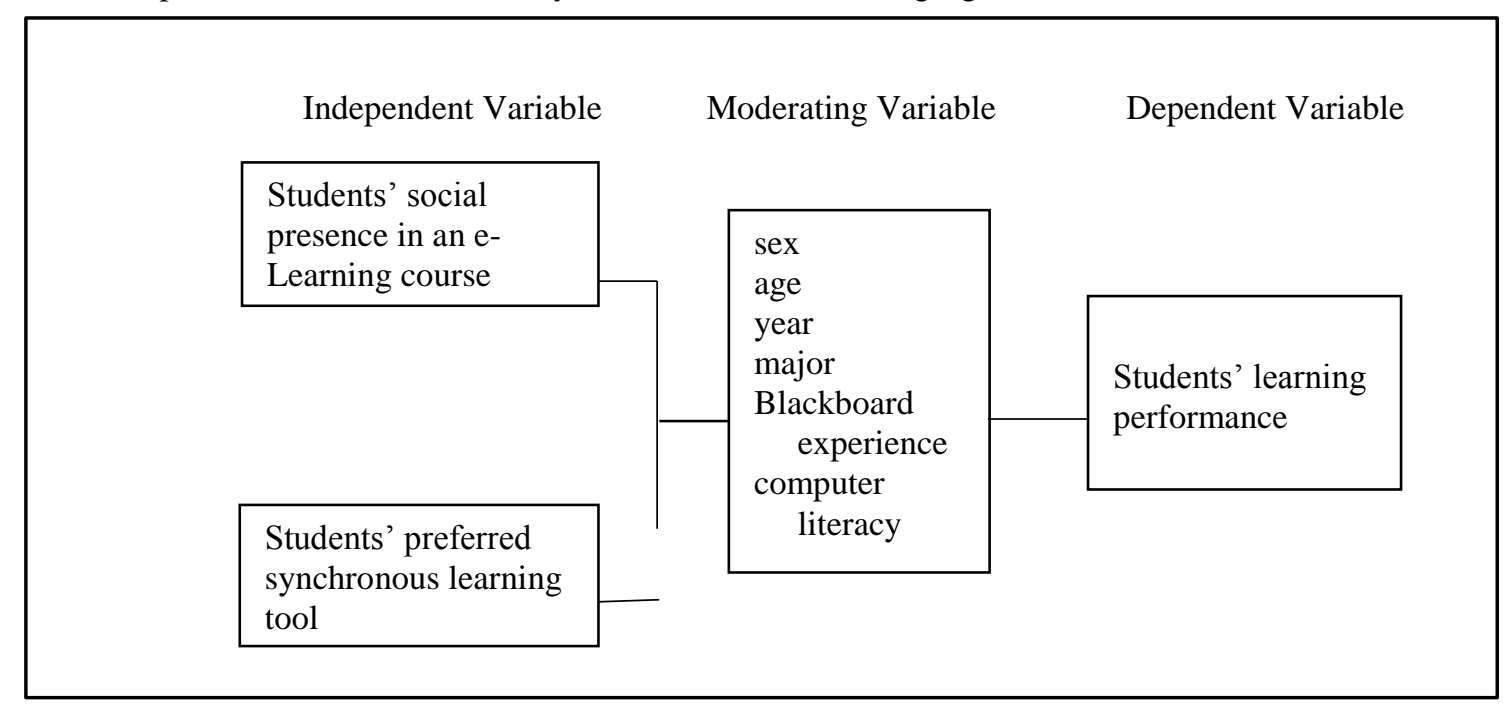

Figure 1. Students' social presence, preferred synchronous learning tool, and learning performance in an

$$
\text { e-Learning class }
$$

\section{Review of the Literature}

\subsection{Social Presence in e-Learning}

The number of e-Learning students, world-wide, is on the rise. Researchers from the Digital Learning Compass organization revealed that as of 2015, the number of college students enrolled in at least one e-Learning course was over 6 million (Allen \& Seaman, 2017). Korea is following a similar trend, where, according to the country's Ministry of Education, there are 19 universities solely dedicated to distance learning. The transition from the traditional classroom to the e-Learning environment has not been without problems, though, notably the ability to retain students throughout the duration of a course compared to that of the conventional, bricks-and-mortar classroom (Doherty, 2006).

In addressing high student turnover, relative to the traditional classroom environment, educators discovered that social presence was lacking (Kear, 2010; So \& Brush, 2008). According to Sung and Meyer (2012), social presence refers 
to "the subjective feeling of being connected and together with others during computer-mediated communication" (p. 1740). Their measurement of social presence includes factors, such as social respect, social sharing, open mind, social identity, and intimacy (Sung \& Meyer, 2012). Gunwardena and Zittle (1997) define social presence as the "degree to which a person is perceived as a 'real person' in mediated communication" (p.9). Additionally, social presence refers to the "ability of participants in a Community of Inquiry to project their personal characteristics into the community, thereby presenting themselves to other participants as real people" (Garrison, Anderson, \& Archer, 2000, pp.89).

Research has shown correlations between social presence and the development of an e-Learning community (Rourke, Anderson, Garrison, \& Archer, 2001; Rovai, 2002), social presence and perceived learning (Richardson \& Swan, 2003), and social presence and student satisfaction (Gunawardena \& Zittle, 1997; Richardson \& Swan, 2003). Due to these correlations, educators and researchers have experimented with various methods to create and sustain social presence in the e-Learning classroom, including audio and video, introduction posts, regular grading and discussion forum feedback (Aragon, 2003). Additionally, social presence has been developed by incorporating tools outside of the Learning Management System, such as text messaging (DuVall, Powell, Hodge, \& Ellis, 2007) and internet-based voice mail (Keil \& Johnson, 2002).

Creating a class environment where the learner is engaged, relaxed, and comfortable when communicating with their classmates, hence, social presence, is a primary objective for e-Learning. Research suggests that this is important and necessary because students are more likely to engage in higher order thinking (Garrison, Anderson, \& Archer, 2000; Garrison, Cleveland-Innes, \& Fung, 2010); participate more actively in e-Learning communications (Cui, Lockee, \& Meng, 2013; Danchak, Walther, \& Swan, 2001); maintain enrollment in the e-Learning course (Bowers \& Kumar, 2015) and show higher levels of e-Learning satisfaction (Gunawardena \& Zittle, 1997; Moallem, 2015; So \& Brush, 2008) when they experience a high degree of social presence in an e-Learning environment. Consequently, social presence has been considered to be a significant and central variable in determining the extent of interaction and effectiveness of the eLearning environment (Borup, West, \& Graham, 2012; Kim, Kwon, \& Cho, 2011; Lobry de Bruyn, 2004; McIsaac \& Gunawardena, 1996; Richardson \& Swan, 2003).

Researchers, Biocca et al. (2003), confirmed that social presence has strong predictive validity of teacher-student relationship satisfaction, class satisfaction, and perceived knowledge gain (three main outcomes in online class experiences). Students state that the interaction with faculty motivates them to overcome challenges and continue working and learners are more intellectually committed when they know their instructors (Chickering \& Ehrmann, 1996). Furthermore, according to Hostetter (2012), social presence influenced learning performance on written assignments in that it revealed that students demonstrating higher levels of social presence in discussion board posts had statistically and remarkably higher ratings on the CAT. Kim et al.'s (2011) study, investigating Korean e-Learning students, showed a correlation between social presence and interactivity but not social presence and learning satisfaction. As students' participation in e-Learning class activities increased, their levels of social presence also increased; they felt more acknowledged by their classmates. Additionally, their research showed that male students had higher levels of both social presence and learning satisfaction than females (Kim et al., 2011).

\subsection{Synchronous Learning Tools in e-Learning}

Synchronous learning is defined as simultaneous interaction between two or more participants. It can be in a form of online chat, instant messaging, white boarding, file sharing, audio conferencing, web conferencing, and videoconferencing (Cook et al., 2008 as cited in Motyeka, Onge, \& Williams, 2013, p.63). Videoconferencing as a synchronous learning tool allows real time interaction between teachers and students and reduces time and travel expenses as well. It is more useful in the academe for important activities such as meetings, teaching, managing different campuses, and even interviews (Reynolds, 2008). Currently, several synchronous tools are utilized as a part of e-Learning curriculums. Cadiz (2000) explains that Distributed Tutored Video Instruction (DTVI) as a form of synchronous learning is used to teach distance learning which involves students in different locations as they meet online to watch and discuss pre-recorded lectures. In addition, Motyeka et al. (2013) attest another form of synchronous learning, Elluminate, which is an online learning platform allowing faculty and students to communicate using headphones and their computer. It further allows live interactions, whiteboard communication, chat messaging, and content sharing.

Meanwhile, Hrastinski (2008) posits that as synchronous e-Learning is supported by media such as videoconferencing and chat, learners can still develop communities since there is still a real time interaction between teachers and 
learners. Parker and Martin (2010) report that synchronous virtual classrooms use web conferencing to enhance interactivity and build a sense of community. In higher education, the most prevalent synchronous tools are Adobe Connect, Blackboard Collaborate, WebEx, Saba Centra, Elluminate Live!, and Wimba Classroom. More research has favorable results in the use of synchronous virtual classrooms, like Park and Bonk (2007) which assert that this type of classroom environment provides immediate feedback, encourages exchange of different perspectives, enhances productive interactions among students and teachers, enhances social presence, and even promotes emotional support. In the study of Parker and Martin (2014) they found out that instructors primarily use the virtual classroom to facilitate instructor-student and student-student dialogue. The virtual classroom was used for instructional purposes or conducting office hours to promote interactivity, develop community, and reach students at different locations.

Elluminate Inc. (2009) explained that the academic benefits of synchronous online learning include: first, it creates effective distance learning which means that live e-Learning enables academic institutions to deliver real-time, instructor-led classes to students, regardless of their geographical location and with all the advantages of traditional face-to-face classrooms. Second, it extends the physical classroom which means that technology enables to connect online and onsite students and instructors can present engaging content onsite and remotely. Third, it builds learning communities by using live e-Learning and web collaboration technology, students can collaborate on projects provide peer mentoring, and create online communities to discuss a variety of topics. Fourth, it enhances professional development, through synchronous e-Learning technology, remote experts can address staff to keep them up-to-date on new technologies, policies, strategies, and teaching methodologies. Fifth, it leverages limited teaching resources, academic institutions are enabled to teach across geographical boundaries. Sixth, it facilitates communication and collaboration, web collaboration technology provides an enhanced meeting environment like web conferencing and virtual live meeting. Lastly, it enhances infrastructure support, using synchronous learning technology in internal training, research, help desk support, and online library resources.

Social networks have become more popular over the past decades. Apparently, these are also useful in the learning process as synchronous tools in online classes. Messaging apps had been a part of daily routines of most people from all walks of life. Statista reported that in 2016, 1.58 billion mobile phone users accessed over-the-top messaging apps to communicate. This figure is projected to grow to 2.48 billion users in 2021. Specifically, in $2015,23.8$ million mobile phone users in South Korea accessed over-the-top messaging apps to communicate. This figure is projected to grow to 28.6 million users in 2019. With over one billion people, worldwide, accessing Facebook, it's not surprising that educators are utilizing it as a teaching and learning tool. Research studies showed that there are numerous benefits associated with using Facebook in the classroom (Bosch, 2009; Lampe et al., 2011). For instance, it was perceived that social learning, knowledge sharing, collaboration, learner-centered activities and educational micro-community development (Bosch, 2009) were enhanced when Facebook was used in the classroom. Furthermore, students believed that English language learning could be strengthened when using Facebook in an e-Learning environment (Kabilan et al., 2010), and Qais showed that Facebook improved English proficiency and vocabulary development (2017). Statista reports that in 2022, the number of Facebook users in South Korea is expected to reach 15.74 million, up from 13.69 million in 2015.

However, with the rise in privacy and security concerns and the shift in Facebook user demographics in recent years, (with younger users preferring alternative social networking platforms) research findings are showing some challenges with using Facebook in the e-Learning classroom. For example, educators are finding it to be more of a challenge to get their students to accept Facebook as a learning tool (Cheung, Chiu, \& Lee, 2011). Furthermore, not all students are comfortable with disclosing personal information in an online environment (Mazer et al., 2007) and there may be a lack of familiarity with accessing and utilizing the account privacy restrictions on Facebook (Boyd \& Hargittai, 2010). Another study indicated that a problem with using Facebook in the online classroom is assessing student performance. It can be difficult and time-intensive for educators to objectively assign a grade based on the quality of content submitted on Facebook (Shaw, 2016).

Another popular networking site, Twitter, is a multiplatform Web 2.0, part social networking - part microblogging tool, freely accessibly on the Web (Stevens, 2008). Other popular Web 2.0 microblogging tools include Jaiku, Tumblr, MySay, and Hictu, and Edmodo. Twitter, however, is one of the most popular of these microblogging tools and therefore, was a tool of choice because it is well-established, has a large and growing participant base, interfaces well with other Web 2.0 tools, and is easily accessible. According to Statista (https://www.statista.com/statistics/282087/ number-of-monthly-active-twitter-users/) twitter is a social networking and microblogging service, enabling registered users to read and post short messages, so-called tweets. Twitter 
messages are limited to 280 characters and users are also able to upload photos or short videos. Tweets are posted to a publicly available profile or can be sent as direct messages to other users. It is one of the most popular social networks worldwide. In 2014, the number of Twitter users in South Korea reached 4.66 million and it increased to 5.13 million in 2016.

Wildly popular in South Korea, KakaoTalk is a free downloadable software application for mobile devices providing free text messaging and call services. It first began as a basic instant messaging service, allowing users to send and receive real-time messages, and then evolved into a global service platform with features such as voice calls, mobile games, and even a social network. It has created a new communications culture: as two out of three Korean mobile users use the mobile app to communicate, people who don't use KakaoTalk feel excluded from their peers (RousseMarquet, 2013). Statista reported that in 2016, 30.3 million South Korean mobile phone users accessed this messaging app to communicate. This figure is projected to grow to 34.1 million users in 2021. KakaoTalk users can share diverse contents and information from photos, videos, voice messages, URL links, and contact information. It began expanding its services in 2010, launching its first non-chat service, the Gift Shop. KakaoTalk introduced more features like "Plus Friends", a feed feature, which allows users to receive special contents and updates from brands and artists they choose as their "Plus Friends"; KakaoPay, which allows users to register up to 20 cards to their accounts via the KakaoPay menu; KakaoStory, which allows users to share pictures and status updates via their phone; and more (Staykove, Kalina, \& Damsgaard, 2016).

Blackboard is a Web-based learning management system (LMS) designed to support fully online courses or provide a space for face-to-face course supplementation. It provides many types of tools and features for enriching the learning experience. (http://www.uta.edu/blackboard/). Blackboard's suite of enterprise applications includes the Blackboard Learning System, Blackboard Community Portal System ${ }^{\mathrm{TM}}$, and Blackboard Transaction System ${ }^{\mathrm{TM}}$. The Blackboard Learning System, used daily by more than 2,000 institutions dedicated to teaching and learning, features an online environment designed to complement and supplement either traditional learning or distance learning. One popular utility in this system is the Blackboard Ultra Collaborate, a virtual classroom and discussion board which provides a rich, multi-functional environment for both synchronous and asynchronous communications. It further affords freeform chat, chat lectures, and question and answer chats.

\subsection{Learning Performance in e-Learning}

Educators and practitioners have been researching the effects of e-Learning on performance and how this differs from that of the conventional, bricks-and-mortar classroom. They have discovered numerous variables involved in eLearning performance, both positive and negative. Castillo-Merino and Serradell-Lopez (2014) showed that the most significant influencer of e-Learning performance for higher education learners was motivation, which was positively determined solely by the learners' perception of their efficiency. Another influential variable implicated in their study was the learners' perceptions about their digital technology capability. However, no correlations existed between previous e-Learning experience and learners' effort and learning performance.

Similar to the present study, Liu et al. (2009) also measured learning/academic performance using the final course grade. The study by Liu et al. (2009) showed a strong statistical correlation between perceived social presence and students' final grades. Furthermore, this study revealed that social presence strongly predicted student retention in the course and led to increased student interaction, resulting in the increased likelihood of students to earn higher grades. Giesber et al.'s (2013) study investigated the effects of tool usage and course participation on learning performance. Results showed that there was a strong correlation between the students' tool usage and the final exam score but an even stronger correlation between the final score and the level of course participation.

When it comes to enhancing learning performance in the online classroom, educators have expanded their tool usage to include not only the standard LMS tools (discussion boards, wikis, blogs, etc.) but social media tools (i.e., Facebook, Twitter, Instagram, etc.) as well. Numerous studies have shown strong correlations between social media interactivity in the e-Learning classroom and learning performance (Nachmias, 2002). There are many positive learning outcomes associated with incorporating social media tools in the online classroom, including "enhancing the autonomous learning abilities, overcoming difficulties, cooperation, contemplative learning, fast/prompt feedback from instructors, decreasing the effect of geographical distances, clarity of students' effort, and the establishment of social dealings between academicians and students" (Al-rahmi et al., 2015). Another well-known benefit of using social media tools was the ease at which knowledge and information was dispersed. For example, Scholarly Twitter users listed information dissemination as one of the main benefits of using social media (Al-rahmi et al., 2014). 


\section{Methodology}

\subsection{Research Design}

This study utilizes a descriptive-correlational method of research. The descriptive method of research which is an attempt to determine, describe, or identify the characteristics or behavior of a sample population (Jackson, 2009). Correlational research explores the interrelationship amongst variables of interest without any active intervention on the part of the researcher (Polit \& Hungler, 2013). The results of the study were described based on the answers obtained through two survey questionnaires. The relationships between the independent and dependent variables were also determined.

\subsection{Participants}

The participants in this study were the ESL students enrolled in a purely online, elective course, Global Business Communication, at the University of Suwon in South Korea in the Spring Semester of academic year 2018-2019. All students had access to the same tools and communication modalities and were required to participate in all activities.

The 29 participants were classified according to sex (male=14, female=15); age (18-20=7, 21-24=14, 25 and over=8); year (first year $=7$, second year $=7$, third year $=7$, fourth year $=8$ ); college (Arts $=3$, Business $=4$, Engineering $=5$, Health and Science $=4$, Humanities $=5$, Information Technology $=5$, and Theater=3); perceived computer literacy level (basic $=15$, intermediate $=10$, advanced $=4$ ); and Blackboard experience ( short=13, long=16).

\subsection{Instruments}

Two online surveys were used in this study. The first survey, which was adapted from the study of Brady, Holcomb, and Smith (2010), determined the students' preferences regarding synchronous tool usage. It is composed of fourteen statements describing the benefits of synchronous tools which are Facebook, KakaoTalk, Twitter, and Blackboard Ultra Collaborate. The tool with the highest survey score indicates the student's preference. The second survey measured students' social presence in online courses and was adopted from Richardson and Swan (2003). It is composed of three parts. Part I is about the students' overall experiences in the e-Learning class; Part II is about the students' experiences on specific activities, both use a 6-point Likert scale ranging from strongly agree (1) to strongly disagree (6). Part III is composed of five specific questions about the e-Learning class. Validity and reliability were established for this survey questionnaire.

\subsection{Data Collection Procedure}

In this study, several synchronous communication tools were adopted: Blackboard Ultra Collaborate, Facebook, Twitter, Instagram, and KakaoTalk (a widely-used Instant Messaging application in South Korea). These were used as supplemental tools as part of the course instruction and enabled students to communicate in real time, utilizing either face-to-face, two-way oral, or two-way text modalities. Throughout the semester, the instructor used synchronous activities. All students were instructed to register accounts for each of these synchronous tools in Week 1 of the course. Synchronous sessions were composed of mandatory one-hour group chat sessions. During the group chat sessions, students discussed case study dilemmas, controversial issues, and course subject matter. The course instructor monitored and facilitated the group chat sessions. Each week, students completed the social presence survey immediately following the synchronous activity.

\subsection{Data Analysis Procedure}

The data gathered in this study were encoded and processed using Statistical Package for the Social Sciences (SPSS). Specifically, the Wilcoxon Signed Rank Test was used to determine the respondents' level of social presence before and after the conduct of the e-Learning course. The Mann-Whitney Test and Kruskal-Wallis Test were used to determine differences. Pearson's $r$ was used to determine significant relationships.

\section{Results}

The results in Table 1 show that the students' overall level of social presence before and after the conduct of the eLearning course is moderately high (before: $\mathrm{M}=2.35$; after: $\mathrm{M}=2.59$ ) although there is an increase of .24 in the mean score after the conduct of the e-Learning course. When grouped according to different variables, the students have a moderately high level of social presence. Apparently, a majority of the higher mean scores are evident after the conduct of the e-Learning course. This means that the e-Learning course meetings somehow influenced the students' social 
presence in the e-Learning course but it's not that significant. Therefore, there is no significant difference in the students' social presence in the e-Learning course according to different variables as well as before and after the conduct of e-Learning course.

Table 1. Students' levels of social presence before and after the conduct of the e-learning course

\begin{tabular}{|c|c|c|c|c|c|c|c|c|c|c|}
\hline \multicolumn{2}{|c|}{ Category } & $\mathrm{N}$ & Mean & & $\mathrm{SD}$ & \multicolumn{2}{|c|}{ Description } & $\mathrm{Z}$ & & $p$-value \\
\hline \multicolumn{2}{|c|}{ Entire Group } & 29 & & & & & & & & \\
\hline \multicolumn{2}{|l|}{ Before } & 2.35 & & .78 & \multicolumn{2}{|c|}{ Moderately High } & 1.114 & & .265 & \\
\hline \multicolumn{2}{|l|}{ After } & 2.59 & & .92 & \multicolumn{3}{|c|}{ Moderately High } & & & \\
\hline \multicolumn{11}{|l|}{ Sex } \\
\hline \multirow[t]{3}{*}{ Male } & 14 & & & & & & & & & \\
\hline & Before & & 2.16 & & .78 & Modera & Iigh & .691 & & .490 \\
\hline & After & & 2.36 & & .76 & Modera & Iigh & & & \\
\hline \multirow[t]{3}{*}{ Female } & 15 & & & & & & & & & \\
\hline & Before & & 2.52 & & .61 & Moderat & High & .739 & & .460 \\
\hline & After & & 2.76 & & 1.04 & Moderat & High & & & \\
\hline
\end{tabular}

Age

18-20 7

\begin{tabular}{|c|c|c|c|c|c|c|}
\hline & Before & 2.51 & .34 & Moderately High & .845 & .398 \\
\hline & After & 2.95 & .96 & Moderately High & & \\
\hline \multirow[t]{3}{*}{$21-24$} & 14 & & & & & \\
\hline & Before & 2.43 & .77 & Moderately High & .911 & .362 \\
\hline & After & 2.67 & .94 & Moderately High & & \\
\hline \multirow[t]{3}{*}{25 and over } & 8 & & & & & \\
\hline & Before & 2.06 & .81 & Moderately High & .140 & .889 \\
\hline & After & 2.05 & .70 & Moderately High & & \\
\hline
\end{tabular}

First year $\quad 7$

$\begin{array}{llllll}\text { Before } & 2.54 & .33 & \text { Moderately High } & .169 & .866 \\ \text { After } & 2.58 & .70 & \text { Moderately High } & & \end{array}$

Second Year 7

\begin{tabular}{|c|c|c|c|c|c|c|}
\hline & Before & 2.47 & .57 & Moderately High & \multirow[t]{2}{*}{1.355} & \multirow[t]{2}{*}{.176} \\
\hline & After & 3.23 & 1.0 & Moderately High & & \\
\hline \multirow[t]{3}{*}{ Third Year } & 7 & & & & \multirow{3}{*}{.845} & \multirow{3}{*}{.398} \\
\hline & Before & 2.16 & .99 & Moderately High & & \\
\hline & After & 1.78 & .87 & Moderately High & & \\
\hline
\end{tabular}




\begin{tabular}{|c|c|c|c|c|c|}
\hline \multicolumn{6}{|l|}{ Fourth Year } \\
\hline Before & 2.25 & .83 & Moderately High & 1.542 & .123 \\
\hline After & 2.66 & .63 & Moderately High & & \\
\hline \multicolumn{6}{|l|}{ Major } \\
\hline \multirow[t]{3}{*}{ Art } & & & & & \\
\hline & 2.48 & .96 & Moderately High & 1.089 & .275 \\
\hline & 2.69 & .81 & Moderately High & & \\
\hline \multirow[t]{2}{*}{ Business } & & & & & \\
\hline & 2.37 & .90 & Moderately High & .365 & .715 \\
\hline After & 2.50 & .58 & Moderately High & & \\
\hline \multicolumn{6}{|l|}{ Engineering } \\
\hline Before & 2.54 & .44 & Moderately High & .674 & .500 \\
\hline After & 2.82 & .64 & Moderately High & & \\
\hline \multicolumn{6}{|l|}{ Health Science 4} \\
\hline Before & 2.71 & .78 & Moderately High & .365 & .715 \\
\hline After & 2.73 & .75 & Moderately High & & \\
\hline \multicolumn{6}{|l|}{ Humanities $\quad 5$} \\
\hline Before & 1.91 & .53 & Moderately High & 1.490 & .136 \\
\hline After & 2.86 & 1.54 & Moderately High & & \\
\hline \multicolumn{6}{|l|}{ Info Tech $\quad 5$} \\
\hline Before & 2.23 & .85 & Moderately High & 1.214 & .225 \\
\hline After & 1.71 & .80 & Moderately High & & \\
\hline Theater & & & & & \\
\hline Before & 2.33 & .82 & Moderately High & 1.069 & .285 \\
\hline After & 2.82 & .81 & Moderately High & & \\
\hline \multicolumn{6}{|c|}{ Computer Literacy Level } \\
\hline \multicolumn{6}{|l|}{ Basic $\quad 15$} \\
\hline Before & 2.30 & .65 & Moderately High & 1.364 & .173 \\
\hline After & 2.70 & 1.06 & Moderately High & & \\
\hline \multicolumn{6}{|l|}{ Intermediate $\quad 10$} \\
\hline Before & 2.37 & .79 & Moderately High & .459 & .646 \\
\hline After & 2.52 & .79 & Moderately High & & \\
\hline \multicolumn{6}{|l|}{ Advanced $\quad 4$} \\
\hline Before & 2.50 & .89 & Moderately High & 1.6444 & .100 \\
\hline After & 2.17 & .72 & Moderately High & & \\
\hline
\end{tabular}




\begin{tabular}{lcccccr} 
Short & \multicolumn{1}{c}{13} & & & & \\
& Before & 2.35 & .61 & Moderately High & 1.644 & .100 \\
& After & 2.71 & .69 & Moderately High & & \\
Long & 16 & & & & & \\
& Before & 2.35 & .80 & Moderately High & .284 & .776 \\
& After & 2.45 & 1.08 & Moderately High_ & & \\
\hline
\end{tabular}

The results in Table 2 show that the students' overall preferred synchronous tool is KakaoTalk $(\mathrm{M}=2.66)$, followed by Blackboard Ultra Collaborate, Facebook, and Twitter, respectively. When grouped according to different variables, KakaoTalk still got the highest mean score among the other tools except for the variable Year, where Facebook has the highest mean score which is the most preferred tool by the third year students. Looking at each variable more specifically, male students prefer KakaoTalk while females prefer Blackboard maybe because females are more serious in their studies and they find Blackboard more helpful for them. Students who belong to 18-22 age bracket are more or less the First Year students, preferred Blackboard. These students are neophytes to the university and maybe are still more diligent on their studies compared with the older and higher level students who have already university life experience. But it doesn't mean that these students are less diligent though.

Moreover, Art and Theater preferred Twitter and Blackboard respectively and the rest of the majors preferred KakaoTalk. As for the Computer Literacy Level, all students preferred KakaoTalk. Lastly, students with long Blackboard experience preferred KakaoTalk while the ones with short experience preferred Blackboard which showed actually a big Mean difference. This maybe because, students with longer experience had too much of the Blackboard activities that they want a more accessible tool to use in their e-Learning class.

Table 2. Preferred synchronous learning tool

\begin{tabular}{lcccl}
\hline \multicolumn{1}{c}{ Category } & N & Mean & SD & Description \\
\hline Entire Group & 29 & 2.66 & 0.95 & KakaoTalk \\
Sex & & & & \\
$\quad$ Male & 14 & 2.86 & 0.92 & KakaoTalk \\
$\quad$ Female & 15 & 2.48 & 0.97 & Blackboard \\
Age & & & & \\
$18-20$ & 7 & 2.44 & 0.75 & Blackboard \\
$21-24$ & 14 & 2.51 & 0.81 & KakaoTalk \\
25 and over & 8 & 3.12 & 1.25 & KakaoTalk \\
Year & & & & \\
$\quad$ First Year & 7 & 2.18 & 0.43 & Blackboard \\
$\quad$ Second Year & 7 & 2.63 & 0.90 & KakaoTalk \\
$\quad$ Third Year & 7 & 3.32 & 1.02 & Facebook \\
$\quad$ Fourth Year & 8 & 2.55 & 1.08 & KakaoTalk \\
Major & & & & \\
$\quad$ Art & 3 & 1.72 & 0.62 & Twitter
\end{tabular}




\begin{tabular}{|c|c|c|c|c|}
\hline Business & 4 & 2.83 & 0.96 & KakaoTalk \\
\hline Engineering & 5 & 2.63 & 0.91 & KakaoTalk \\
\hline Health Science & 4 & 2.94 & 0.98 & KakaoTalk \\
\hline Humanities & 5 & 3.20 & 1.04 & KakaoTalk \\
\hline Info. Technology & 5 & 2.82 & 1.08 & KakaoTalk \\
\hline Theater & 3 & 1.92 & 1.08 & Blackboard \\
\hline \multicolumn{5}{|c|}{ omputer Literacy Level } \\
\hline Basic & 15 & 2.68 & 0.95 & KakaoTalk \\
\hline Intermediate & 10 & 2.65 & 0.86 & KakaoTalk \\
\hline Advanced & 4 & 2.64 & 1.39 & KakaoTalk \\
\hline \multicolumn{5}{|c|}{ lackboard Experience } \\
\hline Short & 13 & 2.19 & 0.46 & Blackboard \\
\hline Long & 16 & 3.05 & 1.07 & KakaoTalk \\
\hline
\end{tabular}

The results in Table 3 show that the students' overall learning performance (final grade) is " $B$ " $(M=80.14)$. The highest learning performance when grouped according to major is "A"; according to year and Blackboard experience is "B+"; and according to sex, age, and computer literacy is "B." There is a significant difference in the students' learning performance when they were grouped according to Blackboard experience. The students with longer Blackboard experience have " $\mathrm{B}+$ " grades while the students with shorter experience have "C" grades. This implies that the longer the students' Blackboard experience, the higher their learning performance in this particular online class, although these students preferred KakaoTalk as a synchronous tool.

Moreover, Female students have higher grade than males although it's not a really a big difference. Noticeably, students from 18-12 age bracket who are more or less are the First Year students have $\mathrm{C}$ and $\mathrm{C}+$ grades while the rest have B grades except for Fourth Year students who got B+ grades. Understandably, they are graduating students so they can't just get low grades as much as possible. Further, Business major students got the A grades for a fact that this is a Business elective class. The rest got $\mathrm{B}, \mathrm{C}+$ and Theater majors got $\mathrm{D}$ grade as it might not be that interesting for them or they didn't put much effort to the class. Lastly, students with Basic Computer Literacy level have C+ and those with Intermediate and Advanced levels had B grades. Since this is an e-learning class, it is apparently an edge to be more knowledgeable with technology in general to cope with the demands of the course. Therefore, there is a significant difference in the students' level of learning performance in the e-learning course only according to Blackboard experience.

Table 3. Students' learning performance

\begin{tabular}{|c|c|c|c|c|c|c|}
\hline & Category & $\mathbf{N}$ & Mean & SD & Description & p-value \\
\hline & Entire Group & 29 & 80.14 & 15.42 & B & \\
\hline \multicolumn{7}{|c|}{ Sex } \\
\hline & Male & 14 & 78.50 & 19.54 & $\mathrm{C}+$ & .914 \\
\hline & Female & 15 & 81.67 & 10.75 & B & \\
\hline \multicolumn{7}{|l|}{ Age } \\
\hline & $18-20$ & 7 & 76.29 & 26.47 & $\mathrm{C}+$ & .686 \\
\hline
\end{tabular}




\begin{tabular}{|c|c|c|c|c|c|}
\hline $21-24$ & 14 & 79.79 & 11.37 & $\mathrm{~B}$ & \\
\hline 25 and up & 8 & 84.12 & 8.78 & $\mathrm{~B}$ & \\
\hline \multicolumn{6}{|l|}{ Year } \\
\hline First Year & 7 & 70.57 & 24.76 & $\mathrm{C}$ & .506 \\
\hline Second Year & 7 & 80.71 & 12.38 & $\mathrm{~B}$ & \\
\hline Third Year & 7 & 82.86 & 10.64 & $\mathrm{~B}$ & \\
\hline Fourth Year & 8 & 85.63 & 7.96 & $\mathrm{~B}+$ & \\
\hline \multicolumn{6}{|l|}{ Major } \\
\hline Art & 3 & 81.67 & 12.58 & B & .304 \\
\hline Business & 4 & 90.25 & 4.86 & A & \\
\hline Engineering & 5 & 81 & 7.71 & B & \\
\hline Health Science & 4 & 81.75 & 13.45 & B & \\
\hline Humanities & 5 & 82.60 & 11.97 & B & \\
\hline Info. Technology & 5 & 74.60 & 30.37 & $\mathrm{C}+$ & \\
\hline Theater & 3 & 66.67 & 5.77 & $\mathrm{D}$ & \\
\hline \multicolumn{6}{|c|}{ Computer Literacy Level } \\
\hline Basic & 15 & 77 & 18.04 & $\mathrm{C}+$ & .586 \\
\hline Intermediate & 10 & 84 & 9.39 & B & \\
\hline Advanced & 4 & 82.25 & 18.17 & B & \\
\hline \multicolumn{6}{|l|}{ Blackboard Experience } \\
\hline Short & 13 & 72 & 18.09 & $\mathrm{C}$ & $.004 *$ \\
\hline Long & 16 & 86.75 & 8.82 & $\mathrm{~B}+$ & \\
\hline
\end{tabular}

The results in Table 4 show that there was no significant relationship between the students' level of social presence and preferred synchronous tool $(\mathrm{r}=.089, \mathrm{p}=.645)$, and learning performance $(\mathrm{r}=.245, \mathrm{p}=.184)$, and learning performance and social presence $(\mathrm{r}=.300, \mathrm{p}=.114)$. This means that social presence does not influence the students' preference of synchronous tool nor their learning performance. All students have moderately high social presence but their choice of synchronous tool and learning performance varies. Therefore, there is no significant relationship between the students' levels of social presence, preferred synchronous tool, and learning performance?

Table 4. Relationship of social presence, preferred synchronous tool, and learning performance

\begin{tabular}{lllll}
\hline & & $\begin{array}{l}\text { Social } \\
\text { Presence }\end{array}$ & $\begin{array}{l}\text { Preferred } \\
\text { Synchronous Tool }\end{array}$ & $\begin{array}{l}\text { Learning } \\
\text { Performance }\end{array}$ \\
\hline Social Presence & Correlation Coefficient & 1.000 & .089 & -.300 \\
& Sig. (2-tailed) & & .645 & .114 \\
& $\mathrm{~N}$ & 29 & 29 & 29
\end{tabular}




\begin{tabular}{|c|c|c|c|c|}
\hline \multirow{3}{*}{$\begin{array}{l}\text { Preferred } \\
\text { Tool }\end{array}$} & Correlation Coefficient & -.089 & 1.000 & .254 \\
\hline & Sig. (2-tailed) & .64 & & .184 \\
\hline & $\mathrm{N}$ & 29 & 29 & 29 \\
\hline \multirow[t]{3}{*}{ Learning Performance } & Correlation Coefficient & -.300 & 254 & 1.000 \\
\hline & Sig. (2-tailed) & .114 & .184 & \\
\hline & $\mathrm{N}$ & 29 & 29 & 29 \\
\hline
\end{tabular}

** Correlation is significant at 0.05 alpha level $(\mathrm{p}<.05)$

\section{Discussion}

The findings regarding students' levels of social presence before and after the conduct of the e-Learning course show that all variables fell within the Moderately High social presence category (2.50-3.25), revealing slightly higher social presence scores on the survey completed at the conclusion of the course than at the beginning of the course in all areas except for those students above 25 years of age, third year students, information technology majors, and students who belong to advanced level of computer literacy. The reasoning behind the decrease in social presence levels for information technology students may be due to the fact that these students, overall, prefer working individually as opposed to collectively in a group, which was how work was completed during course synchronous activities.

For students above 25 years of age, referred to as non-traditional students, the decrease in social presence levels may have been due to the students partaking in a full-time job or family responsibilities. These students may have felt that the requirement of synchronous activities diminished the convenience of online learning. Time management, stress and coping factors of the non-traditional students have been addressed in the study of Forbus et al. (2011) along with their differing online learning attitudes and outcomes (Beaghan, 2013). Similarly, because of the extensive course load typically required of third-year students at this university, the requirement of synchronous activities may have been viewed as a nuisance, resulting in decreased social presence levels. Korean students tend to take the bulk of their major courses during their third year, while completing minimal coursework, internships, and/or job searching activities in the fourth year.

The findings in this study, further indicate that students' levels of social presence are not influenced by age, gender, year of study, college major, computer literacy level, nor level of Blackboard experience. Despite the results of numerous studies corroborating opposite research findings (Joksimovic et al., 2015; Liu et al., 2009; Richardson \& Swan, 2003), these results are not surprising since the means used to express social presence was through the use of synchronous communication activities. Overall, students expressed dissatisfaction at being required to participate in synchronous activities as revealed in correspondence (face-to-face, online messaging, and qualitative survey data) between the students and instructor throughout the semester. However, some studies showed similar findings to the present study. According to Swan and Shih, no significant differences existed in the students' social presence according to gender and LMS experience (2005). Additionally, Kim et al.'s study showed that gender and online learning experience did not significantly influence social presence (2005). Nevertheless, creating a class environment where the learner is engaged, relaxed, and comfortable when communicating with their classmates are important and necessary as researchers suggested that because students are more likely to engage in higher order thinking (Garrison, Anderson, \& Archer, 2000); participate more actively in e-Learning communications (Cui, Lockee, \& Meng, 2013; Danchak, Walther, \& Swan, 2001). Hence, social presence, is a primary objective for e-Learning.

The students' preference of KakaoTalk as a synchronous learning tool is not unexpected. As mentioned, KakaoTalk is the most popular social network in South Korea, so obviously, majority of the students would prefer it as a tool because they are more familiar and comfortable with it. Apparently, in all variables of this study: sex, age, major, computer literacy level, and Blackboard experience, KakaoTalk got the highest mean score among the different categories of each variable except for the variable year, where Facebook got the highest mean score from the third year category. This made Facebook to be mentioned once as well as twitter, making these two least preferred among the popular tools used in this study. The study of Han and Cho (2015) concludes that KakaoTalk is the mobile instant messenger that the vast majority of Korean smartphone users constantly use, and KakaoTalk developed this app as its 
core platform and has provided a variety of follow-up platforms, such as mobile commerce, mobile advertisement, mobile games, etc.

Likewise, Gallagher (2017) points out that South Koreans are accustomed to using technologies and applications developed in and for South Koreans. In fact, they are used to using them at an early age. He further reiterates that KakaoTalk is the dominant social media application and environment in South Korea. Hence, it is deeply integrated into this country's socialized practice, both informal and formal, activated through mobile technology and it is used by university students to maintain participation across informal and formal communities. Moreover, Blackboard Collaborate Ultra is the second synchronous tool preferred by students in this study, probably because it is an online course which they could only access through Blackboard. According to the study of Robinson et al. (2017), the students were interested in seeing an increase in the number of Blackboard courses offered in subsequent semesters. Findings in the study of Asiri and Aly (2018) show that faculty members and students' degree of e-Learning system (Blackboard) use and tools in teaching and learning is very high. The researchers concluded that these results indicate the importance of such learning system in the educational process.

In the study of Sauers and Walker's (2004) students in the hybrid business writing classes displayed higher levels of improvement in their writing than those in the traditional classroom. This improvement was attributed to increase active learning: online discussions and online activities promoted in the online environment. Likewise, the study conducted by Kramarski and Mizrachi (2006) on seventh-grade math classes found that students who participated in online discussion and problem solving outperformed their face-to-face counterparts in math literacy and real-life tasks. Coopman (2009) concluded in her essay that "the technology used to deliver an online class influences how students and instructors interact with one another. More than previous technologies, online learning systems have the potential to enhance the collaborative performative nature of teaching, and at the same time, the potential to turn teaching into a static exercise."

In the case of twitter and Facebook, Kim and Song (2012) evaluated the SNS effects on education by analyzing 153 articles from 2009 to 2012 published in Korea to know the current status of the application of the SNS on education. It was found out that $38 \%$ of the articles are related to language education, such as foreign language learning, especially, using Twitter and Facebook. They attributed the result to the main characteristics of Twitter and Facebook being more appropriate for teaching language with short sentences. Since both Twitter and Facebook are easy to create individual contents and deliver news just adding a few sentences along with communication with short sentences, thus exposure time of language can be increased through students using this SNS. To sum up, students would prefer a tool that is not only comfortable and familiar with them but equally important as well is that they can use their mobile phones in using this tool. Statista reported that in 2016, 1.58 billion mobile phone users accessed over-the-top messaging apps to communicate. This figure is projected to grow to 2.48 billion users in 2021. Students use KakaoTalk in almost all of their online transactions so it is just practical to use it as well for their learning purposes.

Furthermore, the result of this study shows that the students' overall learning performance is "B" (80.14), however, this is the lowest grade in the grade category " $\mathrm{B}$ " $(\mathrm{B}=80-84)$. This implies that the students generally struggled to get a higher grade in this elective online class. In like manner, Business major students got "A" (90.25) but it still belongs to the lowest category $(A=90-94)$. This result can be attributed to the fact that the online elective class in this study is Global Business Communication and these business major students have some amount of familiarity and knowledge of the topics being discussed during discussions. In addition to these results, fourth year students got " $\mathrm{B}+$ " (85.63) which belongs in the middle of the grade category $(\mathrm{B}+=85-89)$. This is somehow expected of higher level students, especially since they are graduating from college, they need to pass the course and if possible get higher grades. Additionally, they have probably had the opportunity to take additional e-Learning or English-based classes as compared to lower-level students.

Another significant result is that, students with longer Blackboard experience received a higher grade " $\mathrm{B}+$ " (86.75) compared with the students with shorter Blackboard experience who got a " $\mathrm{C}$ " $(72)$, though it belongs to the middle of the grade category $(\mathrm{C}=70-74)$. This particular result makes a significant difference with regards to Blackboard experience, specifically, students with longer Blackboard experience have higher learning performance (final grade) compared with students with shorter Blackboard experience. Presumably, students' experience in Blackboard classes gave them the confidence, knowledge, and skills, specifically, learning management system fluency, in online classes.

In the of Castillo-Merino and Serradell-Lopez (2014) one influential variable implicated as a significant influencer of e-Learning performance for higher education learners, aside from motivation, was the learners' perceptions about their 
digital technology capability. Thus in this age of technology, students are fast learners in using the social media and specific social networks which can facilitate their learning.

Similarly, the study of Means, Toyama, Murphy, Bakia, and Jones (2010) reveals that the overall finding of their meta-analysis is that classes with online learning (whether taught completely online or blended), on average, produce stronger student learning outcomes than do classes with solely face-to-face instruction. Students in online conditions performed modestly better, on average, than those learning the same material through traditional face-to-face instruction. Learning outcomes for students who engaged in online learning exceeded those of students receiving faceto-face instruction. A study done by Rodriguez et al. (2006) found that students in a biology course for non-majors who engaged more actively in online discussions also scored higher on the final test. Furthermore, according to Robinson et al. (2017), students who rated themselves as having high computer literacy level felt that Blackboard was advantageous in their learning. However, Davies and Graff (2005) found that frequency of participation in online discussion did not lead to higher grades in a college business course, but those who participated infrequently did earn lower grades.

Results were unanticipated by the researchers in this study regarding the correlations of social presence, preferred synchronous tool, and learning performance. Contraindicative to similar studies conducted outside of Korea, it was expected that when students use a synchronous tool in which they enjoy and are more familiar and comfortable with, social presence levels would undoubtedly raise. Results of the study of Tu and McIsaac (2010) showed that by choosing the right computer-mediated communication medium in an online class, social presence can be improved. Furthermore, it was predicted that this rise in social presence would lead to improved learning performance (Picciano, 2002); the greater one feels connected to his or her peers and instructor, the more engaged one becomes, hence, the more accountable one feels for their course contribution and performance.

On the other hand, Giesber et al. (2013) investigated the effects of tool usage and course participation on learning performance. The results revealed that there was a strong correlation between the students' tool usage and the final exam score but an even stronger correlation between the final score and the level of course participation. Al-rahmi et al. (2015) further posit that there are many positive learning outcomes associated with incorporating social media tools in the online classroom, including enhancing the autonomous learning abilities, overcoming difficulties, cooperation, contemplative learning, fast/prompt feedback from instructors, decreasing the effect of geographical distances, clarity of students' effort, and the establishment of social dealings between academicians and students.

\section{Conclusion}

The participants in this study have a moderately high level of social presence in their online class, both in the pre- and post- surveys with a very slight increase in the post-survey mean scores. The introduction of synchronous communication e-Learning activities excite the students' interest in their online class. However, certain segments of the participants showed decreases, specifically for older students, third-year students, students majoring in information technology, and students with advanced computer literacy. KakaoTalk is the participants' preferred synchronous tool, which is expected since it is the widely-used instant messaging application established in South Korea, with nearly all Koreans having a registered account. This was followed by Blackboard and Facebook. Twitter is the least preferred. Apparently, it is more convenient to the students and they are more familiar with it especially with its entertaining and useful features. The participants overall learning performance is "B" (final grade) and significance difference is revealed in the students' Blackboard experience. The students with longer experience have higher learning performance than the students with shorter experience. Noticeably, exposure to e-Learning classes using the Blackboard platform is more advantageous to students enrolled in the class where this study was conducted. Finally, there is no significant relationship between the students' levels of social presence, preferred synchronous tool, and learning performance. The students' social presence doesn't influence nor affect their preferred synchronous tool and learning performance. Perhaps this is due to the lack of experience Korean students have with taking e-Learning courses.

\subsection{Limitations and Recommendations}

The major limitation in this study was that the sample size was small; only one online course was evaluated. A combination of the increase in the time commitment expected, adherence to the rigid regimen/structure of the experimental course and effect the student requirement to participate in synchronous activities would have on the professor's end-of-course teacher evaluation score led to the lack of instructor participation in this research study. 
Regarding the teacher evaluation score, a 15\% decrease occurred between the prior and present semester's classes, resulting in one of the lowest evaluation scores in the college. The only course curriculum changes made included the addition of synchronous activities and preference surveys. Students' comments on the end-of-semester survey included: "Online discussion is really inconvenient. For learners, think about why they take online classes instead of offline?" and "I think that student-to-student interaction is difficult in online education. This is because we are unfamiliar with each other and unfamiliar with the electronic devices and programs." To remedy this problem, it would be best to conduct this study at a time when all e-Learning teachers are utilizing synchronous communication within their courses. When students see that their peers enrolled in other e-learning courses are also expected to participate in synchronous activities, their regard for synchronous communication may be viewed as a requirement and customary (as is at a number of universities across the U.S. and Europe) and may improve.

Another limitation was that Korean students disliked the privacy and security concerns surrounding the use of Facebook and expressed their desires to discontinue using it in the middle of the semester. One student stated, "Now, I am constantly receiving advertisement pop-ups when I never used to before I registered for Facebook and it's very inconvenient." Additionally, the Korean students enrolled in this course were much less familiar with using Twitter. Over half of the students in the class didn't have an account or experience with using this social networking site. It would be interesting to see the effects of using more familiar, Generation Z-preferred synchronous communication tools, such as Snapchat or Instagram, in the e-Learning classroom. Therefore, the researchers of this study recommend that online educators gravitate towards using those synchronous tools in which a majority of the students currently use (are comfortable and familiar with) in the country or region in which the class is being conducted, such as Messenger in the U.S. and KakaoTalk in South Korea.

\section{Funding}

This study was supported by the Research Grant of The University of Suwon in 2017

\section{References}

Allen, I. E., \& Seaman, J. (2017). Digital learning compass: Distance education enrollment report. Babson Survey Research Group, e-Literate, and WCET. https://onlinelearningsurvey.com/reports/digtiallearningcompassenrollment2017.pdf

Al-rahmi, W., Othman, M., \& Musa, M. (2014). The improvement of students' academic performance by using social media through collaborative learning in Malaysian higher education. Asian Social Science, 10(8), 210-221. doi: $10.5539 /$ ass.v10n8p210

Al-Rahmi, W., Othman, M. S., \& Yusuf, L. M. (2015). The role of social media for collaborative learning to improve academic performance of students and researchers in Malaysian higher education. Int. Rev. Res. Open Distrib. Learn., 16(4), 177-204. doi: 10.19173/irrodl.v16i4.2326

Aragon, S. (2003). Creating social presence in online environments. New directions for adult and continuing education. San Francisco, 100, 57-68. https://www.learntechlib.org/p/73882/

Asiri, A. A. M., \& Aly, H. S. (2018). An evaluative study for the use reality of e-Learning systems and tools in teaching and learning by faculty members and students. World Journal of Education, 8(1), 37-48. doi: https://doi.org/10.5430/wje.v8n1p37

Beaghan, J. P. (2013). Non-traditional student performance and attitudes toward online and other forms of distance learning. Rev. Bus. Res, 13, 23-28. doi: 10.18374/RBR-13-1.3

Bioca, F., Harms, C., \& Burgoon, J. K. (2003). Towards a more robust theory and measure of social presence: Review and suggested criteria. Presence: Tele-operators and Virtual Environments, 12(5), 456480. doi:10.1162/105474603322761270

Borup, J., West, R. E., \& Graham, C. R. (2012). Improving online social presence through asynchronous video. The Internet and Higher Education, 15(3), 195-203. doi:10.1016/j.iheduc.2011.11.001

Bosch, T. (2009). Using online social networking for teaching and learning: Facebook use at the University of Cape Town. South African Journal for Communication and Research, 35(2), 185-200. doi:10.1080/02500160903250648 
Bower, M., Dalgarno, B., Kennedy, G. E., Lee, M. W. J., \& Kenney, J. (2015). Design and implementation factors in blended synchronous learning environments: Outcomes from a cross-case analysis. Computers \& Education, 86, 1-17. https://doi.org/10.1016/j.compedu.2015.03.006

Bowers, J., \& Kumar, P. (2015). Students' perceptions of teaching and social presence: A comparative analysis of face-to-face and online learning environments. International Journal of Web-Based Learning and Teaching Technologies, 10(1), 27-44. https://doi.org/10.4018/ijwltt.2015010103

Boyd, D., \& Hargittai, E. (2010). Facebook privacy settings: Who cares? First Monday, 15(8). https://firstmonday.org/article/view/3086/2589

Brady, K. P., Holcomb, L. B., \& Smith, B. V. (2010). The use of alternative social networking sites in higher educational settings: A case study of the E-Learning benefits of Ning in education. Journal of Interactive Online Learning, 9(2), 151-170. https://www.learntechlib.org/p/109412/

Cadiz, J. (2000). Distance learning through distributed collaborative video viewing. Proceedings of the 2000 ACM conference on Computer supported cooperative work, 135-144. https://doi.org/10.1145/358916.358984

Castillo-Merino, D., \& Serradell-Lopez, E. (2014). An analysis of the determinants of students' performance in elearning. Computers in Human Behavior, 30, 476-484. https://doi.org/10.1016/j.chb.2013.06.020

Cheung, C. M. K., Chiu, P. Y., \& Lee, M. K. O. (2011). Online social networks: Why do students use Facebook? Computers in Human Behavior, 27(4), 1337-1343. https://doi.org/10.1016/j.chb.2010.07.028

Chickering, A. W., \& Ehrmann, S. C. (1996). Implementing the seven principles of good practice in undergraduate education: Technology as lever. Accounting Education News, 49, 9-10. https://www.researchgate.net/publication/246430027_Implementing_the_Seven_Principles_Technology_as_ Lever

Coopman, S. J. (2009). A critical investigation of Blackboard's e-learning environment. First Monday, 14(6). doi: 10.5210/fm.v14i6.2434

Cui, G., Lockee, B., \& Meng, C. (2013). Building modern online social presence: A review of social presence theory and its instructional design implications for future trends. Education and Information Technologies, 18(4), 661-685. doi: 10.1007/s10639-012-9192-1

Danchak, M. M., Walther, J. B., \& Swan, K. P. (2001). Presence in mediated instruction: bandwidth, behavior, and expectancy violations. Paper presented at the 7 th Sloan-C international conference on asynchronous learning networks (ALN), Orlando, FL, November, 17-19.

Davies, J., \& Graff, M. (2005). Performance in e-learning: online participation and student grades. British Journal of Educational Technology, 36(4), 657-663. doi: 10.1111/j.1467-8535.2005.00542.x

Doherty, W. (2006). An analysis of multiple factors affecting retention in web-based community college courses. Internet and Higher Education, 9(4), 245-255. doi:10.1016/j.iheduc.2006.08.004

Duncan, K., Kenworthy, A., \& McNamara, R. (2012). The effect of synchronous and asynchronous participation on students' performance in online accounting courses. Accounting Education, 21(4), 431-449. https://doi.org/10.1080/09639284.2012.673387

DuVall, J. B., Powell, M. R., Hodge, E., \& Ellis, M. (2007). Text messaging to improve social presence in online learning. Educause Quarterly, 30(3), 24-28. https://er.educause.edu/articles/2007/7/text messaging-toimprove-social-presence-in-online-learning

Ellis, R., Pardo, A., \& Han, F. (2016). Quality in blended learning environments-Significant differences in how students approach learning collaborations. Computers \& Education, 102, 90-102. https://doi.org/10.1016/j.compedu.2016.07.006

Elluminate, Inc. (2009). The impact of synchronous online learning on academic institutions customer experiences from $\mathrm{K}-12$ and higher education. Elluminate, Inc. 
Forbus, P., Newbold, J. J., \& Mehta, S. S. (2011). A study of non-traditional and traditional students in terms of their time management behaviors, stress factors, and coping strategies. Academy of Educational Leadership Journal, 15, 109-125.

Francescucci, A., \& Rohan, L. (2018). Exclusively synchronous online (VIRI) learning: The impact on student performance and engagement outcomes. Journal of Marketing Education, 41(1), 60-69. https://doi.org/10.1177/0273475318818864

Gallagher, M. S. (2017). KakaoTalk meets the ministry of education: mobile learning in South Korean higher education. $\quad$ https://www.research.ed.ac.uk/portal/en/publications/kakaotalk-meets-the-ministry-ofeducation(a8389bed-ba30-4c39-8796-5f8c0c6b9b30).html

Garrison, D. R., Anderson, T., \& Archer, W. (2000). Critical inquiry in a text-based environment: Computer conferencing in higher education. The Internet and Higher Education, 2(2-3), 87-105. https://doi.org/10.1016/S1096-7516(00)00016-6

Giesbers, B., Bart, R., Dirk, T., \& Gijselaers, W. (2013). Investigating the relations between motivation, tool use, participation, and performance in an e-learning course using web-videoconferencing. Computers in Human Behavior, 29(1), 285-292. https://doi.org/10.1016/j.chb.2012.09.005

Gunawardena, C. N., \& Zittle, F. J. (1997). Social presence as a predictor of satisfaction within a computer-mediated conferencing environment. The American Journal of Distance Education, 11(3), 826. https://doi.org/10.1080/08923649709526970

Han, J., \& Cho, O. (2015). Platform business eco-model evolution: case study on KakaoTalk in Korea. J. Open Innov, 1, 6. https://doi.org/10.1186/s40852-015-0006-8

Hostetter, C. (2012). Social presence and learning outcomes. In T. Amiel \& B. Wilson (Eds.), Proceedings of Ed Media 2012--World Conference on Educational Media and Technology (pp. 912-919). Denver, Colorado, USA: Association for the Advancement of Computing in Education (AACE). https://www.learntechlib.org/p/40862/

Hrastinski, S. (2008). Asynchronous and synchronous E-learning. A study of asynchronous and synchronous elearning methods discovered that each supports different purposes. EDUCAUSE Quarterly, 31(4). https://er.educause.edu/articles/2008/11/asynchronous-and-synchronous-elearning

Joksimovic, S., Gasevic, D., Kovanovic, V., \& Riecke, B. (2015). Social presence in online discussions as a process predictor of academic performance. Journal of Computer Assisted Learning, 31(6), 638-654. https://doi.org/10.1111/jcal.12107

Kabilan, M. K., Ahmad, N., \& Abidin, M. J. Z. (2010). Facebook: An online environment for learning of English in institutions of higher education? Internet and Higher Education, 13(4), 179-187. doi: 10.1016/j.iheduc.2010.07.003

Kear, K. (2010). Social presence in online learning communities. In Proceedings of the $7^{\text {th }}$ International Conference on Networked Learning (NLC2010) (pp. 541-548).

Keill, M., \& Johnson, R. D. (2002). Feedback channels: Using social presence theory to compare voice mail to Email. Journal of Information Systems Education, 13(4), 295-302. https://www.semanticscholar.org/paper/Feedback-Channels\%3A-Using-Social-Presence-Theory-to-KeilJohnson/484a0ca9197311aca4cf7bea1e98056b4923d5cf

Kim, J., Kwon, Y., \& Cho, D. (2011). Investigating factors that influence social presence and learning outcomes in distance higher education. Computers and Education, 57(2), 15121520. https://doi.org/10.1016/j.compedu.2011.02.005

Kim, K. J., Liu, S., \& Bonk, C. J. (2005). Online MBA students' perceptions of online learning: Benefits, challenges, and suggestions. Internet and Higher Education, 8(4), 335-344. https://www.learntechlib.org/p/102621/

Kim, S. H., \& Song, K. S. (2012). A meta-analysis on the application of SNS in education for SMART learning: Focusing on Korean case. Creative Education, 3(8), 82-85. doi: 10.4236/ce.2012.38B018 
Kramarski, B., \& Mizrachi, N. (2006). Online discussion and self-regulated learning: effects of instructional methods on mathematical literacy. Journal of Educational Research, 99(4), 218-231. http://dx.doi.org/10.3200/JOER.99.4.218-231

Lampe, C., Wohn, D. Y., Vitak, J., Ellison, N. B., \& Wash, R. (2011). Student use of Facebook for organizing collaborative classroom activities. International Journal of Computer-Supported Collaborative Learning, 6(3), 329-347. doi: 10.1007/s11412-011-9115-y

Lee, B. C., Yoon, J. O., \& Lee, I. (2009). Learners' acceptance of e-learning in South Korea: Theories and results. Computers \& Education, 53(4), 1320-1329. https://doi.org/10.1016/j.compedu.2009.06.014

Liu, S. Y., Gomez, J., \& Yen, C. J. (2009). Community college online course retention and final grade: Predictability of social presence. Journal of Interactive Online Learning, 8(2), 165-182. https://eric.ed.gov/?id=EJ938828

Lobry de Bruyn, L. (2004). Monitoring online communication: Can the development of convergence and social presence indicate an interactive learning environment? Distance Education, 25(1), 6781. doi:10.1080/0158791042000212468

Mazer, J. P., Murphy, R. E., \& Simonds, C. J. (2007). I'll see you on "Facebook": The effects of computer-mediated teacher self-disclosure on student motivation, affective learning, and classroom climate. Communication Education, 56(1), 1-17. doi: 10.1080/03634520601009710

McIsaac, M. S., \& Gunawardena, C. N. (1996). Distance education. In J. H. Jonassen (Ed.), Handbook of research for educational communications and technology (pp. 403-437). Englewood Cliffs, NJ: Educational Technology Publications.

Means, B., Toyama, Y., Murphy, R., Bakia, M., \& Jones, K. (2010). Evaluation of evidence-based practices in online learning: A meta-analysis and review of online learning studies. U.S. Department of Education, Office of Planning, Evaluation, and Policy Development, Policy and Program Studies Service. https://www2.ed.gov/rschstat/eval/tech/evidence-based-practices/finalreport.pdf

Moallem, M. (2015). The impact of synchronous and asynchronous communication tools on learner self-regulation, social presence, immediacy, intimacy, and satisfaction in collaborative online learning. The Online Journal of Distance Education and e-Learning, 55-77. https://www.tojdel.net/journals/tojdel/articles/v03i03/v03i03-08.pdf

Motycka, C. A., Erin, L. S., Onge, E. L., \& Williams, J. (2013). Asynchronous versus synchronous learning in pharmacy education. Journal of Curriculum and Teaching, 2(1), 63-67. http://dx.doi.org/10.5430/jct.v2n1p63

Nachmias, R. (2002). A research framework for the study of a campus-wide web-based academic instructional project. The Internet and Higher Education, 5(3), 213-229. https://doi.org/10.1016/S1096-7516(02)00103-3

Nagel, L., Blignaut, S., \& Cronje, J. (2009). Read-only participants: a case for student communication in online classes. Interactive Learning Environments, 17(1), 37-51.doi: 10.1080/10494820701501028

Qais, F. (2017). Effectiveness of Facebook in English language learning: A case study. Institute of Education Sciences, 4, 1-11. https://eric.ed.gov/?id=ED581701

Park, Y., \& Bonk, C. (2007). Is online like a breeze? A case study for promoting synchronous learning in a blended graduate course. MERLOT Journal of Online Learning and Teaching, 3(3), 307-323. https://jolt.merlot.org/vol3no3/park.htm

Parker, M. A., \& Martin, F. (2010). Using virtual classrooms: Student perceptions of features and characteristics in an online and a blended course. MERLOT Journal of Online Learning and Teaching, 6(1) 135-137. https://jolt.merlot.org/vol6no1/parker_0310.pdf

Parker, M. A., \& Martin, F. (2014). Use of synchronous virtual classrooms: Why, who, and how? MERLOT Journal of Online Learning and Teaching, 102-210. 265335172_Use_of_Synchronous_Virtual_Classrooms_Why_Who_and_How_MERLOT_Journal_of_Onlin e_Learning_and_Teaching_10_2_192 
Picciano, A. (2002). Beyond student perceptions: Issues of interaction, presence, and Performance in an Online Course. JALN, 6(1). doi: 10.24059/olj.v6i1.1870

Polit, D. F., \& Hungler, B. P. (2013). Essentials of nursing research: Methods, appraisal, and utilization (8th ed.). Philadelphia: Wolters Kluwer/Lippincott Williams and Wilkins.

Rabinowitch, T. C., \& Knafo-Noam, A. (2015). Synchronous rhythmic interaction enhances children's perceived similarity and closeness towards each other. PLoS ONE, 10(4). doi:10.1371/journal.pone.0120878

Reynolds, P., Keaton, K., \& Mason, R. (2008). Seeing is believing: Dental education benefits from developments in videoconferencing. British Dental Journal, 204(2), 87-92. doi: 10.1038/bdj.2008.9

Richardson, J. C., \& Swan, K. (2003). Examining social presence in online courses in relation to students' perceived learning and satisfaction. Journal of Asynchronous Learning Networks, 7(1), 68-88. doi: 10.24059/olj.v7i1.1864

Robinson, G., Basco, L., Mathews, Y., Dancel, R., Princena, M. A., \& McKeever, M. (2017). ESL student perceptions of VLE effectiveness at a university in South Korea. Journal of Language Teaching and Research, 8(5), 847857. http://www.academypublication.com/ojs/index.php/jltr/article/view/jltr0805847857

Rodriguez-Fernandez, M., Egea, J. A., \& Banga, J. R. (2006). Novel metaheuristic for parameter estimation in nonlinear dynamic biological systems. BMC Bioinformatics, 7, 483.

Rourke, L., Anderson, T., Garrison, D. R., \& Archer, W. (2001). Methodological issues in the content analysis of computer conference transcripts. International Journal of Artificial Intelligence in Education, 12, 8-22. https://telearn.archives-ouvertes.fr/hal-00197319

Rousse-Marquet, J. (2013). KakaoTalk, the Korean messaging App turned social phenomenon. INA Global.

Rovai, A. (2002). Building sense of community at a distance. The International Review of Research in Open and Distributed Learning, 3(1). Athabasca University Press. Retrieved December 15, 2020 from https://www.learntechlib.org/p/49515/

Sauers, D., \& Walker, R. C. (2004). A comparison of traditional and technology-assisted instructional methods in the business communication classroom. Business Communication Quarterly, 67(4), 430-442. http://dx.doi.org/10.1177/1080569904271030

Shaw, C. M. (2016). Connecting students cross-nationally through Facebook. Journal of Political Science Education, 12(3), 353-368. doi: 10.1080/15512169.2015.1115741

Smith, G., Sorensen, C., Gump, A., Heindel, A., Caris, M., \& Martinez, C. (2011). Overcoming student resistance to group work: Online versus face-to-face. The Internet and Higher Education, 14(2), 121-128. doi: $\underline{10.1016 / j . i h e d u c .2010 .09 .005}$

So, H. J., \& Brush, T. A. (2008). Student perceptions of collaborative learning, social presence and satisfaction in a blended learning environment: Relationships and critical factors. Computers and Education, 51, 318336. doi:10.1016/j.compedu.2007.05.009

Statista Research Department (2015). South Korea: Number of mobile messaging users 2014-2019 (in millions). https://www.statista.com/statistics/485633/number-of-mobile-messaging-users-south-korea/

Statista Research Department (2016). South Korea: Number of Twitter users 2014 to 2016. https://www.statista.com/statistics/558435/number-of-twitter-users-in-south-korea/

Staykova, K. S., \& Damsgaard, J. (2016). Platform expansion design as strategic choice: The case of Wechat and KakaoTalk. Research Papers, 78. https://aisel.aisnet.org/ecis2016 rp/78

Statista Research Department (2017). South Korea: number of Facebook users 2015-2022. https://www.statista.com/statistics/304833/number-of-facebook-users-in-south-korea/

Statista Research Department (2017). Number of KakaoTalk users in South Korea from 2016 to 2021 (in millions). https://www.statista.com/statistics/736561/number-of-kakaotalk-users-south-korea/ 
Stevens, V. (2008). Trial by twitter: The rise and slide of the year's most viral microblogging platform. TESLEJ: Teaching English as a Second or Foreign Language, 12(1). http://tesl-ej.org/ej45/int.html

Sung, E., \& Mayer, R. E. (2012). Five facets of social presence in online distance education. Computers in Human Behavior, 28(5), 1738-1747. https://doi.org/10.1016/j.chb.2012.04.014

Swan, K., \& Shih, L. F. (2005). On the nature and development of social presence in online course discussions. Journal of Asynchronous Learning 115-136. https://olj.onlinelearningconsortium.org/index.php/olj/article/view/1788 https://doi.org/10.24059/olj.v9i3.1788

Tu, C. H., \& McIsaac, M. (2002). The relationship of social presence and interaction in online classes. The American Journal of Distance Education, 16(3), 131-150. https://doi.org/10.1207/S15389286AJDE1603_2

Wang, S. K. (2008). The effects of a synchronous communication tool (Yahoo Messenger) on online learners' sense of community and their multimedia authoring skills. Journal of Interactive Online Learning, 7(1), 59-74. https://www.ncolr.org/issues/jiol/v7/n1/the-effects-of-a-synchronous-communication-tool-yahoo-messengeron-online-learners-sense-of-community-and-their-multimedia-authoring-skills.html 